\title{
Determinants of Corporate Reputation: A Study of Consumers' Perspective of Malaysian Aviation Company
}

Su-Lin Tay, Tak-Jie Chan, Nurul Ain Mohd Hasan

To Link this Article: http://dx.doi.org/10.6007/IJARBSS/v10-i11/7972

DOI:10.6007/IJARBSS/v10-i11/7972

Received: 17 September 2020, Revised: 20 October 2020, Accepted: 10 November 2020

Published Online: 29 November 2020

In-Text Citation: (Tay, Chan, \& Hasan, 2020)

To Cite this Article: Tay, S-L., Chan, T-J., \& Hasan, N. A. M. (2020). Determinants of Corporate Reputation: A Study of Consumers' Perspective of Malaysian Aviation Company. International Journal of Academic Research in Business and Social Sciences. 10(11), 756-770.

Copyright: (c) 2020 The Author(s)

Published by Human Resource Management Academic Research Society (www.hrmars.com) This article is published under the Creative Commons Attribution (CC BY 4.0) license. Anyone may reproduce, distribute, translate and create derivative works of this article (for both commercial and non-commercial purposes), subject to full attribution to the original publication and authors. The full terms of this license may be seen at: http://creativecommons.org/licences/by/4.0/legalcode

Vol. 10, No. 11, 2020, Pg. 756 - 770

Full Terms \& Conditions of access and use can be found at http://hrmars.com/index.php/pages/detail/publication-ethics 


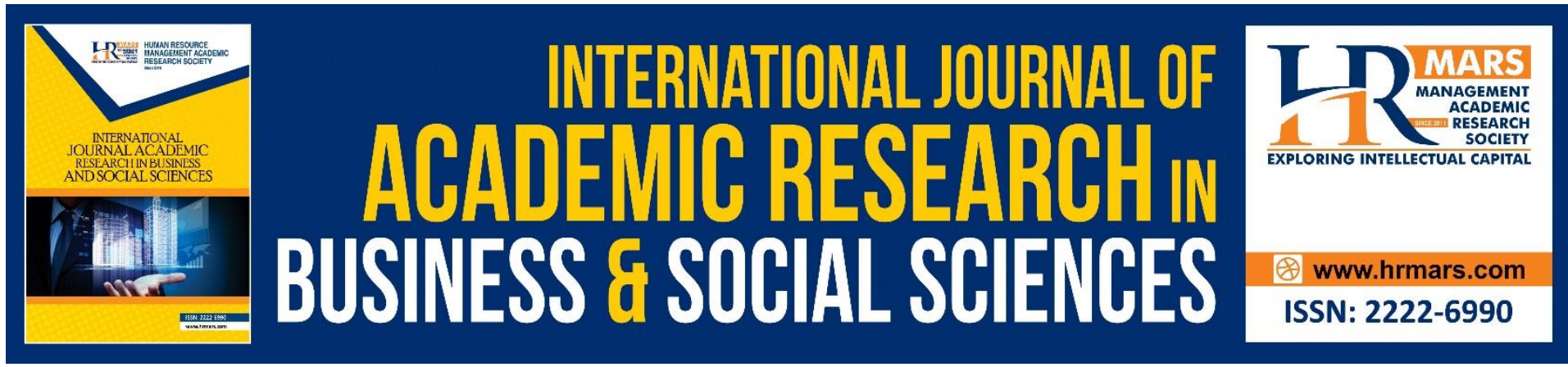

\title{
Determinants of Corporate Reputation: A Study of Consumers' Perspective of Malaysian Aviation Company
}

\author{
Su-Lin Tay, Tak-Jie Chan \\ Faculty of Business, Social Sciences and Hospitality Management, SEGi University, 47810, \\ Petaling Jaya, Selangor, Malaysia. \\ Email: sulin.tay0401@gmail.com,chantakjie@segi.edu.my
}

\begin{abstract}
Nurul Ain Mohd Hasan
Faculty of Modern Languages and Communication, Universiti Putra Malaysia, 43400, UPM

Serdang, Selangor, Malaysia

Email: namh@upm.edu.my
\end{abstract}

\begin{abstract}
This study examined the predicting factors of selected facets of RepTrak ${ }^{\mathrm{TM}}$ reputation model $^{2}$ (products/services, innovation, citizenship, leadership, performance) and corporate reputation of Malaysia Airlines Berhad, from consumers' perspective. Utilizing the Fombrun's (2006) RepTrak ${ }^{T M}$ reputation model, this model served as a guide to the study. Survey questionnaires were used to gather the data, in which the researchers distributed the questionnaires online and in-person to the Malaysia Airlines consumers who had prior encounters with the airline company. A 173 valid responses were yielded as the results. The collected data was then analysed through Pearson's Product-Moment Correlation and Multiple Regression using Statistical Package for the Social Sciences (SPSS) version 24.0. The findings of the Pearson's product-moment correlation analysis showed that the associations between product and services, innovation, citizenship, performance, and corporate reputation have a significantly positive moderate relationship. Meanwhile, the correlations between leadership and corporate reputation have a significantly positive high relationship. In addition, multiple regression analysis revealed that products/services, innovation, citizenship, leadership, and performance were the significant predicting variables, which explained $71.9 \%$ of the variance of corporate reputation. Conclusion, limitations, suggestions, and implications of this study were discussed.
\end{abstract}

Keywords: Reputation, RepTrak ${ }^{\mathrm{TM}}$ Model, Customer, Aviation Industry, Corporate \& Strategic Communication Management.

\section{Introduction}

Corporate reputation has become a significant area of corporate communication with examining the multi-faceted and multi-layered dimensions of stakeholders and their 
perceptions towards a corporation (Argenti, 2015; Cornellissen, 2017). Corporate reputation is commonly known as an intangible asset (Bronn \& Buhmann, 2018; Fisher-Buttinger \& Vallaster, 2011) and is perceived closely related to the survival and sustainability of an organization (Chan, Leong, Nadarajan \& Ramayah, 2016; Chan, Sathasevam, Muhammad Noor, Khiruddin \& Hasan, 2018; Gatzert \& Schmit, 2016), especially during a crisis where the company's credibility are usually in doubt (Wei, Ouyang, Chen, 2017).

Understanding the advantages of having a strong and positive reputation, many organizations have recognized the relevance of building favourable reputation in their long-term survival to enhance the organizational and marketing performance (Eckert, 2017, Goldring, 2015), particularly in times of uncertainties where big data opens up to the spread of unverified information shared through the social media making corporations vulnerable to attacks from the publics (Dutot, Galvez, \& Versailles, 2016).

Of late, large Malaysian companies have experienced some major reputational damages, such as, the major crises experienced by a national aircraft carrier, Malaysia Airline System (MAS), rebranded as Malaysia Airlines Berhad (MAB) underwent major reputational loss internationally in 2014. The reputational damage was due to the occurrence of double tragedies in four-month time of their aircrafts, $\mathrm{MH} 370$ and $\mathrm{MH} 17$. The reputational damage of MAB is tremendous with a drop in ranking from $18^{\text {th }}$ to $34^{\text {th }}$ place in four years (2014-2018) in 'The World's Top 100 Airlines' award (Skytrax World Airline Awards, 2018).

The outcome appeared far more damaging than was expected particularly when, MAB was not listed in the 'Top 100 Reputable Companies around the Globe' based on 2018 Global RepTrak $^{\circledR} 100$ (Reputation Institute, 2018). MAB suffered a net loss of RM 750.43 million in the first half of 2014, an increase by $65 \%$ compared with the previous year's net loss of RM 454.81 million (Chin, 2014). The damages that MAB suffered were not only monetary loss, but the loss of trust as a reliable aircraft carrier has deepened its negative image with the increase of customers not willing to choose MAB as a preferred choice for travelling (Adapa, \& Roy, 2017; Worlu \& Ahmad, 2019). The reputational damages that the MAB suffered are aligned with Fombrun's notion of the snowballing effect of crisis towards a company's reputation, in which he stated, "the value of a corporate reputation is magnified" during crisis (Fombrun \& Van Riel, 2004, p. 34-35).

Based on the above notion, thus, reputation management is increasingly the focal point of research (Chan et al., 2016; Chan et al., 2018; Dutot et al., 2016; Eckert, 2017; Gatzert \& Schmit, 2016; Wei, Yu \& Chen, 2017). Since then, researchers have come up with various concepts and models to conceptualize and measure corporate reputation, including the "World's Most Admired Companies" ranking by Fortune Magazine, Reputation Quotient (RQ) and RepTrak ${ }^{\mathrm{TM}}$ reputation model developed by Charles Fombrun (Eckert, 2017). The current research intends to adopt the RepTrak ${ }^{\mathrm{TM}}$ reputation model (extension from $\mathrm{RQ}$ ) because this model is still understudied, particularly in the context of developing countries like Malaysia (Chan et al., 2018; Kanto, de Run, \& Isa, 2013).

In addition, although several past studies have used the application of RQ and RepTrak ${ }^{\mathrm{TM}}$ reputation model to examine the reputation of the corporations, particularly in the industries related to food and beverages (Mohd Sah \& Abdullah, 2014), health care, tourism, manufacturing (Rungnapar Pitpreecha, 2013), education (Chan \& Hasan, 2019), and banking (Kanto, de Run, \& Md Isa, 2016). However, there is a limited research that look into the aviation industry. Hence, this research attempts to apply the selected RepTrak ${ }^{\mathrm{TM}}$ reputation model and examine in the Malaysian aviation industry, focusing on MAB, to examine the perception of current customers regard the reputation of the company. 
Therefore, the current study aimed to find out the predicting factors of the selected RepTrak $^{T M}$ reputation model (products/services, innovation, citizenship, leadership, performance) and corporate reputation of MAB.

\section{Literature Review}

\section{RepTrak $^{\mathrm{TM}}$ Reputation Model}

RepTrak $^{\mathrm{TM}}$ reputation model, developed by Fombrun (2006), is a measuring instrument for quantifying perceived corporate reputation with rating score ranges from 0 to 100 . The model attempts to explain stakeholders' behaviours resulted from pulse (trust, admire, feeling and esteem) that is interrelated with perceptions of stakeholders towards an organization. These perceptions are built on the seven dimensions or aspects as proposed by the model (Reputation Institute, 2018). The dimensions are products/services, innovation, workplace, governance, citizenship, leadership and performance (Fombrun, Ponzi, \& Newburry, 2015).

\section{Relationships between Selected Facets of RepTrak ${ }^{\mathrm{TM}}$ Model and Corporate Reputation}

Past studies have shown the determinants of RepTrak have been positively associated with corporate reputation. For instance, Feldman, Bahamonde and Bellido, (2013) conducted a comparative study and associated the enhanced product/service quality, higher visibility of CSR activities, higher productivity, stronger competitive advantages and increased market worth as the outcomes of enhanced reputation. The findings illustrated there is a positive association between Products/Services, Citizenship, Performance and corporate reputation (Feldman et al., 2013). Based on the discussion above, this has further supported the study of Rungnapar Pitpreecha (2013) who ranked Products/Services as the most important contributor to the reputation in Thailand business companies.

On the other hand, Kanto et al., (2016), wish to examine the RQ in Malaysian banking industry. Based on the confirmatory factor analysis, the findings concluded that the five (5) multidimensional of $R Q$, namely emotional appeal, products and services, financial performance, vision and leadership, and social responsibility are highly important in the Malaysian banking industry. However, the workplace environment is not the determinant factor. This is supported by the study of Mohd Sah and Abdullah (2014), where workplace has perceived very low among customers. In addition, the findings of Rungnapar Pirpreecha (2013) showed that governance has no influence on corporate reputation. Therefore, the current study analysed only five dimensions, namely product and services, innovation, citizenship, leadership and performance because those dimensions are more pertinent to customer orientation.

Foroudi, Jin, Gupta, Melewar and Foroudi (2016) argued that innovation and stronger ability to launch products/services first in the market is extremely beneficial in boosting reputation. Being innovative means possessing an advantage that distinguishes from the other rivals (Fang, Palmatier \& Grewal, 2011). For example, previous findings pointed out the fact that innovation possesses less to no significance in predicting corporate reputation (Feldman et al., 2013; Vidaver-Cohen \& Bronn, 2013). However, other researchers disagree with the findings as they have confirmed that innovation drives reputation (Dangelico, 2015; Dutot et al., 2016; Foroudi et al., 2016; Makkonen \& Inkinen, 2014). It is interesting to note that countries with developing economy prioritizes dimensions which are more business-oriented, and innovation is seen as an indispensable asset (Vidaver-Cohen \& Bronn, 2013).

Citizenship is frequently used interchangeably with corporate social responsibility (CSR) given that, one of the elements under the umbrella of CSR highlights a corporation's responsibility 
towards community engagement and often is connected to the social and environmental influences of economic activities (Lu, Abeysekera, \& Cortese, 2015). Numerous research has confirmed the significant and positive association between citizenship and reputation (Lu et al., 2015; Lü, Jing, \& Cao, 2014; Ogunfowora, 2014; Taghian, D’Souza, \& Polonsky, 2015; Zhu, Sun \& Leung, 2013). For instance, Lu et al., (2015) theorized that perceived acts of CSR positively affect corporate reputation, which makes the quality of CSR reporting essential in creating a favorable image. As business organizations demonstrate their fulfilment to exert the influence of the society and environment positively, it will create a desired impression which helps to build reputation (Lu et al., 2015; Taghian et al., 2015).

A recent study done by Park (2019) also found that CSR has a positive significant influence on corporate reputation in the airline industry through the customer satisfaction and attitude as the moderators. Thus, based on the above discussion, citizenship is a significant attribute contributing as a reputational driver (Vidaver-Cohen \& Bronn, 2013). This further supported Orlitzky and Swanson's (2012) notion that stakeholders will admire and respect organizations that carry out good deeds to society and the environment.

Leaders tend to be viewed as a form of representation of their respective organizations. Stakeholders expect the leader's personality to reflect on the organization. As such, "ethical leadership" has come to life. Brown, Treviño and Harrison (2005) defined ethical leadership as "the demonstration of normatively appropriate conduct through personal actions and interpersonal relationships, and the promotion of such conduct to followers through two-way communication, reinforcement and decision-making" (p. 120). Often times, and ideally, ethical leaders display desirable traits of morality, integrity, fairness, accountability, authenticity, and trustworthiness. They hold themselves accountable for their actions, and simultaneously use reward-punishment system for others who should also take responsibility for their actions. Ethical leaders are morally obligated to offer products and services that are harmless to consumers, be honest and transparent about their business operations, and be concerned with social and environmental impacts of their economic activities (Zhu et al., 2013). This suggests that Leadership dimension can be associated with the betterment of, Products/Services, Citizenship and Performance.

There are studies which showed alignment with the significant and positive association between leadership and corporate reputation (Men, 2014; Ogunfowora, 2014; Zhu, 2014). For instance, Stavrinoudis and Chrysanthopoulou (2017) aimed to investigate the role of leadership in building corporate reputation of reputable hotel. The results showed that charismatic leadership elements have a significant positive influence on the reputation. Based on the above discussion, it is found that appealing leadership has significant and positive influence on corporate reputation as a good and appealing leader is a catalyst for enhancing the trust and admiration of the stakeholders (Halff, 2013).

Last but not least, it is found that performance contributes to the corporate reputation. Numerous past studies has presented findings on the significant and positive association between corporate performance and reputation (Lu et al., 2015; Ogunfowora, 2014; Taghian et al., 2015; Zhu et al., 2013; Zhu, 2014). Perceived excellence of corporate performance is theorized to create the impression that an organization has a desirable reputation (Lu et al., 2015). Meanwhile, other researchers deduced that that positive reputation triggers confidence and supportive attitudes among stakeholders, which leads to enhanced performance (Feldman et al., 2013; Taghian et al., 2015; Zhu et al., 2013). For instance, Vig, Dumicic, and Klopotan (2017) investigated the relationship between corporate reputation and financial performance in Croatia. The findings revealed that products and services, 
corporate integrity, and organizational performance are predictors contributing to the financial performance. This implies that reputation contributes positively to financial performance. Based on the discussion above, excellent and solid reputation is a prominent tool that helps the organization to generate profit and sustain its financial performance and promote future growth continuously. Hence, future profitability is the strength of an organization's to sustain outstanding performances.

Based on the discussion of past studies above, therefore, researchers conceptualize and hypothesized that:

Determinants of selected RepTrak Facets

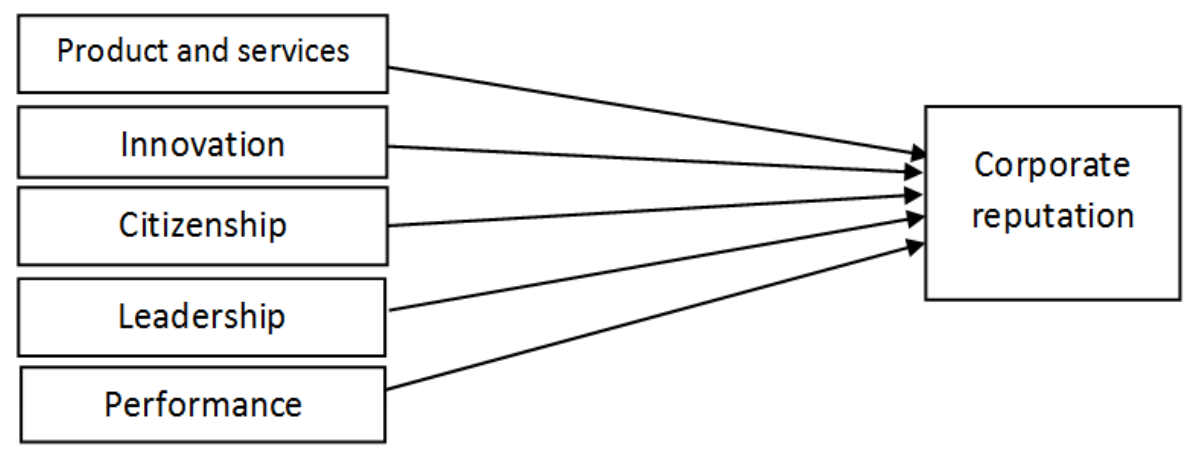

Figure 1: Conceptual between determinants of RepTrak reputation facets and corporate reputation

$\mathrm{H}_{1}$ : There are positive relationships between dimensions of $\operatorname{RepTrak}^{\mathrm{TM}}$ model (product/services, innovative, citizenship, leadership, performance) and corporate reputation.

$\mathbf{H}_{1 \mathrm{a}}$ : There is a positive relationship between the quality of products /services and corporate reputation.

$\mathbf{H}_{\mathbf{1 b}}$ : There is a positive relationship between innovation and corporate reputation.

$\mathbf{H}_{1 c}$ : There is a positive relationship between corporate citizenship and corporate reputation.

$\mathbf{H}_{1 \mathbf{d}}$ : There is a positive relationship between leadership and corporate reputation.

$\mathrm{H}_{1 \mathrm{e}}$ : There is a positive relationship between performance and corporate reputation.

$\mathbf{H}_{\mathbf{2}}$ : Dimensions of RepTrak ${ }^{\mathrm{TM}}$ model (product/services, innovation, citizenship, leadership, performance) are the predicting factors that contribute to the corporate reputation of MAB.

\section{Methodology}

\section{Research Design}

This study utilized quantitative (survey) design to solicit the responses from the MAB's consumers who have experiences using the services provided by the company. Survey method was selected because it was more cost-effective and time-efficient to gather large responses from the identify population (de Leeuw, 2008). According to Babbie (2015), survey design is a suitable method to apply in this study as it allows the researchers to measure effectively the attitudes and opinions of respondents in a large population.

\section{Population and Sampling Procedures}

The sampling technique adopted in this study was purposive sampling. The concept of purposive sampling is the focus on subjects who possess particular characteristics which could be a more specific targeted group to help with the research (Etikan, Musa \& Alkassim, 2016). 
The reasons for using this sampling is because researchers identified the consumers of MAB who had first-hand experiences with the company because they would have a better understanding of the overall company performance, thus enabling them to provide answers for the research. For data collection, a structured anonymous questionnaire were distributed to the customers of MAB and generated 173 valid responses. According to Sekaran and Bougie (2016), a sample size ranging from 30 to 500 is sufficient and acceptable for social science studies.

\section{Research Instrument \& Operationalization of Variables}

The instrument is comprised of three (3) sections. Section A inquired about the demographic background of the respondents. Section $B$ measured the independent variables which are the selected five dimensions of the RepTrak ${ }^{\mathrm{TM}}$ reputation model, whereas Section $\mathrm{C}$ measured the dependent variable which is corporate reputation. The survey questions were all designed in English language and measure with 5-point Likert-type scale, ranging from 1 as 'strongly disagree' to 5 as 'strongly agree'

Demographic question in Section A were designed to solicit information related to gender, age, race, highest education level, nationality, frequency and year of consumer experience. For Section B, the items were adopted from the research work of Fombrun et al., (2015). These questions were based on the 17 attributes of the independent variables which are the selected determinants of the RepTrak ${ }^{\mathrm{TM}}$ reputation model and were measured based on 5 point Likert-type scale. The dimensions are products/services, innovation, citizenship, leadership and performance. For Section C, corporate reputation items were measured through four (4) items which encompassed trust, admire, feeling and esteem which adopted completely from Ponzi, Fombrun and Gardberg (2011).

\section{Pilot Testing}

In order to assess the reliability of the study, pilot test was conducted to measure the internal consistency of the instrument, in which alpha coefficient of 0.70 and above is regarded as acceptable and reliable (Bruin, 2006). This has further supported the notion of Nunnally (1978) and Pallant (2007) that Cronbach's alpha value above 0.70 is considered as reliable and acceptable. Table 1 presents the Cronbach's alpha values of the variables. The Cronbach's alpha values obtained from range from 0.738 to 0.844 , where all of the value is exceeded the threshold of 0.70 . Hence, the data obtained are considered reliable and acceptable for this study.

Table 1: Cronbach's alpha value of the variables

\begin{tabular}{lccc}
\hline Variable(s) & $\begin{array}{c}\text { No. of } \\
\text { items }\end{array}$ & $\begin{array}{c}\text { Cronbach's Alpha Value } \\
\text { (Pre-Test, n=30) }\end{array}$ & $\begin{array}{c}\text { Cronbach's Alpha Value } \\
\text { (Post-Test, n=173) }\end{array}$ \\
\hline $\begin{array}{l}\text { Determinants of selected } \\
\text { RepTrak }\end{array}$ & & & \\
Products and Services & 4 & 0.805 & 0.869 \\
Innovation & 3 & 0.738 & 0.826 \\
Citizenship & 3 & 0.754 & 0.791 \\
Leadership & 4 & 0.759 & 0.886 \\
Performance & 3 & 0.844 & 0.891 \\
Corporate Reputation & 4 & 0.837 & 0.901 \\
\hline
\end{tabular}


Moreover, before multivariate analysis was carried out, the data should be normally distributed, as normality is one of the significant requirements for inferential analysis (Hair, Black, Babin \& Anderson, 2018; Tabachnick \& Fidell, 2013). Based on Table 2, the values for skewness and kurtosis for independent and dependent variables are in the range between -2 to +2 , with a $5 \%$ sampling errors, which is considered acceptable to prove that a normal distribution exists (Tabachnick \& Fidell, 2013). Hence, the data are normally distributed and the requirements for multivariate analysis are met.

In addition, multicollinearity is an issue for regression analyses when there are strong correlations (linear dependency) between independent variables $(r \geq 0.90)$. Therefore the Variance Inflation Factor (VIF) and tolerance level are used to diagnose multicollinearity issue (George \& Mallery, 2016; Tabachnick \& Fidell, 2013; Thompson, Kim, Aloe \& Becker, 2017). According to Hair, et al., (2018), VIF should be below 10 and tolerance value should be above 0.10 to deduce the absence of multicollinearity issue (Kumari, 2008). Table 2 shows the VIF and tolerance values of five (5) independent variables. Tolerance values range from 0.228 to 0.564 which above 0.10 , whereas VIF values range from 1.772 to 4.390 which are below the value of 10 (Tabachnick \& Fidell, 2013). Thus, there is no multicollinearity issue in the study and the statistical requirements are met.

Table 2: Skewness, kurtosis, tolerance and VIF of the variables

\begin{tabular}{|c|c|c|c|c|c|c|}
\hline Variable(s) & Min & Max & Skewness & Kurtosis & Tolerance & VIF \\
\hline \multicolumn{7}{|c|}{ Determinants of } \\
\hline \multicolumn{7}{|l|}{ Selected RepTrak ${ }^{\mathrm{TM}}$} \\
\hline Products/Services & 4.00 & 20.00 & -0.466 & 0.361 & 0.564 & 1.772 \\
\hline Innovation & 3.00 & 15.00 & -0.284 & 0.310 & 0.382 & 2.621 \\
\hline Citizenship & 3.00 & 15.00 & 0.158 & 0.107 & 0.475 & 2.106 \\
\hline Leadership & 4.00 & 20.00 & -0.400 & 0.291 & 0.228 & 4.390 \\
\hline Performance & 3.00 & 15.00 & -0.363 & -0.339 & 0.334 & 2.998 \\
\hline Corporate Reputation & 4.00 & 20.00 & -0.358 & -0.064 & & \\
\hline
\end{tabular}

\section{Results \& Discussions}

The results indicated that more than half of the respondents were female (53.8\%). Over half of the respondents were Chinese (63.6\%), Malaysian (74.0\%) and/or have received tertiary education up to bachelor degree level (54.9\%). Majority of the respondents were represented by the young adults aged between 21 to 30 years old (82.1\%).

Table 3 illustrates the Pearson's product-moment correlations among the variables and indicates a series of positive and moderate relationships between Products/Services $(r=$ 0.698, $p=0.000)$, Innovation $(r=0.600, p=0.000)$, Citizenship $(r=0.699, p=0.000)$, Performance $(r=0.634, p=0.000)$ and Corporate Reputation. In addition, Leadership ( $r=$ $0.778, p=0.000$ ) and Corporate Reputation have a positive and high correlation according to the Rule of Thumb (Mukaka, 2012; Guilford, 1956). With $p$ values less than 0.05 , the correlations are statistically significant. Thus, research hypotheses $H_{1}, H_{1} a, H_{1} b, H_{1} c, H_{1} d$, and $\mathrm{H}_{1} \mathrm{e}$ were supported. This means that when consumers perceived the determinants of Malaysia Airlines' (products/services, innovation, citizenship, leadership, and performance) positively, the company is likely to have a favorable reputation among the consumers. 
Table 3: Correlation test on the relationship between selected determinants of RepTrak ${ }^{\mathrm{TM}}$ model and corporate reputation among consumers of Malaysia Airlines $(n=173)$

\begin{tabular}{lcc}
\hline & \multicolumn{2}{c}{ Corporate Reputation } \\
\cline { 2 - 3 } Independent variable(s) & $\boldsymbol{p}$ & $\boldsymbol{p}$ \\
\hline Dimensions of RepTrak ${ }^{\mathrm{TM}}$ Model & & \\
Products/Services & $0.698^{* *}$ & 0.000 \\
Innovation & $0.600^{* *}$ & 0.000 \\
Citizenship & $0.699^{* *}$ & 0.000 \\
Leadership & $0.778^{* *}$ & 0.000 \\
Performance & $0.634^{* *}$ & 0.000 \\
\hline
\end{tabular}

${ }^{* *}$ Correlation is significant at the 0.01 level (1-tailed)

The current findings supported the findings conducted by Feldman et al., (2013) and Rungnapar Pitpreecha (2013) in which perception of quality product/services can help to enhance reputation. In addition, other research has also confirmed the significant and positive association between citizenship and reputation (Lu et al., 2015; Ogunfowora, 2014; Park, 2019; Taghian et al., 2015; Zhu et al., 2013). Researchers also presented findings on the significant and positive association between corporate performance and reputation, by elaborating that desirable reputation correlates with outstanding performance (Lu et al., 2015; Ogunfowora, 2014; Taghian et al., 2015; Vig et al., 2017; Zhu et al., 2013; Zhu, 2014). For the innovation facet, previous studies revealed perceived higher capability to innovate new thing drives reputation (Foroudi et al., 2016). Innovativeness portrays distinguishing uniqueness to the stakeholders against competitors, thereby creating a desirable reputation that warrants higher visibility (Dutot et al., 2016; Makkonen \& Inkinen, 2014). Dangelico (2015) also supports the current findings by deducing that green product innovation has the ability to improve reputation.

The current findings further supported the significant and positive relationship between leadership and corporate reputation. Based on the findings, many scholars have argued that ethical leaders' characteristics include fairness, integrity, credibility, authenticity, ethicality, desirable managerial values and interpersonal skills are vital to build a positive organizational reputation since leaders are the representative of an entire organization in the eyes of the stakeholders (Halff, 2013; Men, 2014; Ogunfowora, 2014; Zhu, 2014).

Table 4 summarizes the results of multiple regression analysis regarding corporate reputation explained by the determinants of RepTrak ${ }^{T M}$ model. The $R$ value of 0.853 shows a high correlation between corporate reputation and the overall predicting variables (determinants of RepTrak). The analysis of variance with $F=89.070$ was significant at the 0.05 level of significance. Thus, $\mathrm{H}_{2}$ is supported. While the five (5) predictors collectively contributed to $71.9 \%$ of the variation. The analysis clearly indicated that product and service, innovation, citizenship, leadership, and performance were the factors that contributed to corporate reputation of MAB. However, there are other variables (28.1\%) that are currently not explained in this study that contribute incrementally to corporate reputation. 
Table 4: Multiple regression analysis of corporate reputation with predictor variables

\begin{tabular}{lcccc}
\hline Predictor Variables & Unstandardized & Coefficients & $\begin{array}{c}\text { Standardized } \\
\text { Coefficients } \\
\text { Beta }\end{array}$ & P \\
$\begin{array}{l}\text { Determinants of } \\
\text { RepTrak }{ }^{\text {TM }} \text { Model }\end{array}$ & B & Std. Error & & \\
\hline (Constant) & -1.691 & 0.799 & 0.321 & 0.036 \\
Products/Services & 0.430 & 0.066 & -0.138 & 0.037 \\
Innovation & -0.206 & 0.098 & 0.282 & 0.000 \\
Citizenship & 0.462 & 0.096 & 0.345 & 0.000 \\
Leadership & 0.358 & 0.088 & 0.156 & 0.027 \\
Performance & 0.196 & 0.088 & \\
\hline & $\mathrm{F}=89.070 \quad \mathrm{df}_{1}=5, \mathrm{df}_{2}=167 \quad \mathrm{p}=0.000$ & \\
& $\mathrm{R}=0.853 \quad \mathrm{R}^{2}=0.727$ & Adjust $\mathrm{R}^{2}=0.719$ &
\end{tabular}

The findings of products/services being a significant predictor of corporate reputation supported past studies done by Vidaver-Cohen and Bronn (2013) and Rungnapar Pitpreecha (2013) who ranked Products/Services as the most crucial predictor of corporate reputation, meanwhile other researchers deduced that the quality of products and services drives reputation significantly (Feldman et al., 2013). A study conducted by Gatzert and Schmit (2016) concluded that it is also possible for consumers to judge the quality of products and services based on the reputation of the brand. This is likely to happen when consumers have no direct experience with the products and services, and have a limited credible source of information to make a purchase decision. Since, purposive sampling technique is currently employed in this study, all participating respondents will have prior experiences with the products and services of MAB. It is more likely for them to make a judgement based on personal experience to decide if their perception of $M A B$ is favourable or vice versa. Therefore, the claim made by Gatzert and Schmit (2016) is not applied in this study.

In addition, the hypothesis of innovation being the one of the predictors of corporate reputation are also accepted. This finding contradicts with the previous findings on less to no significance of the dimension in predicting corporate reputation (Feldman et al., 2013; Vidaver-Cohen \& Bronn, 2013). However, other researchers would agree with the current findings as they have deduced that innovation drives reputation (Dangelico, 2015; Dutot et al., 2016; Foroudi et al., 2016; Makkonen \& Inkinen, 2014). This finding also supports the study carried out by Vidaver-Cohen and Bronn (2013) who stated that countries with developing economy prioritise dimensions which are more business-oriented, with Innovation being on top of the ranking. This means that Innovation should be highly prioritized by the MAB's consumers in consideration of its reputation.

Based on the results, citizenship is perceived to be one of the significant predicting factors of corporate reputation of MAB. This finding is congruent with the findings found in America, Switzerland, Japan, and across Europe and Latin America whereby the respondents of past RepTrak $^{T M}$ surveys placed Citizenship as the third most significant reputational driver (Vidaver-Cohen \& Bronn, 2013). Other researchers also highlighted the role of CSR as an influencing factor of corporate reputation (Feldman et al., 2013; Park, 2019; Taghian et al., 2015; Zhu et al., 2013).

Based on the discussion, the favourable CSR approach will help with the boost of confidence and positive feelings from stakeholders through portraying excellence in management and achieving common good (Taghian et al., 2015; Zhu et al., 2013). With the emergence of ethical 
consumers, corporate reputation now heavily based upon social and environmental contributions, considering CSR as one of the key factors of long-term sustainability (Feldman et al., 2013).

Current findings on leadership as one of the significant predictors of corporate reputation are also supported (Zhu et al., 2013; Zhu, 2014). It is found that ethical leadership has significant and positive influence on corporate reputation through enhanced CSR approach, but only when ethical leadership is strong. CSR projects without dedication and consistency tend to create a negative impression among stakeholders who will view the CSR-related activities as a greenwashing attempt. Such impression ultimately destroys reputation instead of uplifting it (Zhu et al., 2013).

The hypothesis for performance as a predictor of corporate reputation is also accepted. Desirable financial performance is said to create an impression that an organization has a good corporate reputation (Lu et al., 2015). On the other hand, other researchers have pointed out that positive reputation tends to generate positive sentiments and supportive behaviors among stakeholders, which naturally contributes to better performance such as increased market value, dedicated employees, increased revenue, positive word-of-mouth and stronger customer loyalty (Feldman et al., 2013; Taghian et al., 2015; Zhu et al., 2013).

\section{Conclusion}

This research intends to examine the relationships between the five (5) dimensions of the RepTrak $^{\mathrm{TM}}$ reputation model and corporate reputation of Malaysia Airlines. It aims to determine the perceived relevance of dimensions in reputation management from the MAB consumers' perspective which are products/services, innovation, citizenship, leadership and performance in this study. The correlation and multiple regression results revealed that all the five (5) determinants are the predictors of corporate reputation within the context of this study.

\section{Implications}

In terms of academic implications, this research contributed to the communication management literature empirically by proving that the RepTrak ${ }^{\mathrm{TM}}$ reputation model which was developed by Fombrun et al., (2015) is applicable in the Malaysian setting. The study has widened the knowledge regarding the practicality and suitability of the RepTrak ${ }^{\mathrm{TM}}$ reputation model in the aviation industry operating under a developing economy like Malaysia, and within a multicultural and multiracial environment.

In practical terms, this study brings multiple benefits to the corporate and marketing communication department of MAB in terms of understanding its consumers' perspectives

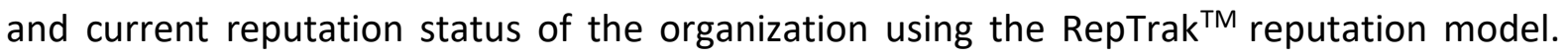
Businesses with similar settings and cultures are also able to identify the variables that are in play when managing their respective reputations.

Since all the determinants, namely products/services, innovation, citizenship, leadership and performance are found to contribute significantly to reputation, the organizations should pay particular attention to these determinants. For instance, the top management and leaders of airline companies should advocate for and implement green product innovation and usage in their daily operations. Green product certifications could be obtained to gain stronger confidence and higher admiration among all stakeholders as well. Ultimately, the findings will inspire the airline companies to re-evaluate the effectiveness of their business and 
communication strategies to convey to the stakeholders in achieving consistent sustainability and survival.

\section{Limitations \& Suggestions for Future Study}

The study possesses several limitations. Firstly, this study has employed a non-probability sampling technique, namely purposive sampling which would limit the generalizability of the results since not everyone in the population were given equal chances to participate in the study. Future studies are recommended to employ probability sampling techniques under similar context, so that there will be more generalizability of the data.

Secondly, this study only focused on the customers as one of the stakeholders of MAB. Future research should therefore include different combinations of stakeholder groups (such as employees, media, potential customer). It is also interesting to make comparisons between different brand of airline companies or industries to add more perspectives into the reputation research.

Thirdly, there are other variables, which were currently not being investigated in this study, which can contribute $28.1 \%$ of the variation in explaining corporate reputation. Hence, future studies can include some other outcome variables as suggested by literature such as customer loyalty, positive word-of-mouth, customer' satisfaction to test the moderating and mediating effects of the reputation model using structural equation modelling (SEM) to enhance the advancement of knowledge in the corporate communication and management arena.

\section{References}

Adapa, S., \& Roy, S. K. (2017). Case study 6: Malaysian Airlines versus AirAsia: Customer satisfaction, service quality and service branding. In Services Marketing Cases in Emerging Markets (pp. 67- 75). Springer International Publishing.

Argenti, P. (2015). Corporate Communication ( $7^{\text {th }}$ ed.). Boston: McGraw-Hill

Babbie, E. R. (2015). The Practice of Social Research (14 ${ }^{\text {th }}$ ed.). Cengage Learning.

Bronn P. S., \& Buhmann, A. (2018). Building and managing reputation: Current debates and future directions. In A. Sasson, A. (ed.). Research-Based Answers to Contemporary Uncertainties of Management, (pp. 59-72), Oslo: Universitetsforlaget

Brown, M. E., Trevino, L. K., \& Harrison, D. A. (2005). Ethical leadership: A social learning perspective for construct development and testing. Organizational Behavior and Human Decision Processes, 97, 117-134. doi: 10.1016/j.obhdp.2005.03.002

Bruin, J. (2006). What does Cronbach's Alpha mean? Retrieved from https://stats.idre.ucla.edu/spss/faq/what-does-cronbachs-alpha-mean/

Chan, T. J., Leong, S. Y., Nadarajan, P., \& Ramayah, P. (2016). A review of reputation facets of selected public-listed companies in Malaysia based on RepTrak ${ }^{\mathrm{TM}}$ Model. Journal of Human Capital Development, 9(2), 1-20.

Chan, T. J., Sathasevam, T., Noor, M. P. N., Khiruddin, A. M., \& Hasan, M. N. A. (2018). Application of selected facets of RepTrak ${ }^{\mathrm{TM}}$ reputation model on Carlsberg Malaysia as one of the companies in tobacco, gambling, alcohol and pornography (TGAP) industry. International Journal of Academic Research in Business and Social Sciences, 8(1), 203-217. doi: 10.6007/IJARBSS/v8-i1/3804

Chan, T. J., \& Hasan, M. N. A. (2019). Student's perception on selected facets of Reputation Quotient: A case of a Malaysian public university. Journal of Arts \& Social Sciences, 2(2), 66-76. 
Chin, J. (2014). Tragedies of $M H 370, M H 17$ deal severe blow to MAB results. Retrieved from https://www.thestar.com.my/business/business-news/2014/08/28/malaysiaairlines-posts-net-losses-of-rm307m-in-q2/

Cornelissen, J. (2017). Corporate Communication: A Guide to Theory and Practice. ( $5^{\text {th }}$ ed.). London: Sage Publications.

Dangelico, R. M. (2015). Green product innovation: Where we are and where we are going. Business Strategy and the Environment, 25(8), 1-17. doi: 10.1002/bse.1886

De Leeuw, E. D. (2008). Choosing the method of data collection. In de Leeuw, E. D., Hox J. J., \& Dillman D. A. (Eds.), International Handbook of Survey Methodology (pp. 113-135). New York: Lawrence Erlbaum Associates. doi: 10.4324/9780203843123.ch7

Dutot, V., Galvez, E. L., \& Versailles, D. W. (2016). CSR communications strategies through social media and influence on e-reputation: An exploratory study. Management Decision, 54(2), 363-389. doi: 10.1108/MD-01-2015-0015

Eckert, C. (2017). Corporate reputation and reputation risk: Definition and measurement from a (risk) management perspective. The Journal of Risk Finance, 18(2), 145-158. doi: 10.1108/JRF-06-2016-0075

Etikan, I., Musa, S. A., \& Alkassim, R. S. (2016). Comparison of convenience sampling and purposive sampling. American Journal of Theoretical and Applied Statistics, 5(1), 1-4. doi: 10.11648/j.ajtas.20160501.11

Fang, E., Palmatier, R. W., \& Grewal, R. (2011). Effects of customer and innovation asset configuration strategies on firm performance. Journal of Marketing Research, 48(3), 587-602.

Feldman, P. M., Bahamonde, R. A., \& Bellido, I. V. (2013). A new approach for measuring corporate reputation. Journal of Business Management, 54(1), 53-66. doi: 10.1590/S0034-759020140102

Fisher-Buttinger, C., \& Vallaster, C. (2011). Corporate branding and corporate reputation: Divided by a shared purpose? In Reputation Management (pp. 59-73). Berlin: Springer.

Fombrun, C. (2006). The RepTrak system. Paper presented at $10^{\text {th }}$ Anniversary Conference on Reputation, Image, Identity, and Competitiveness, New York.

Fombrun, C. J., Ponzi, L. J., \& Newburry, W. (2015). Stakeholder tracking and analysis: The RepTrak $^{\circledR}$ system for measuring corporate reputation. Corporate Reputation Review, 18(1), 3-24. doi: 10.1057/crr.2014.21

Fombrun, C. J., \& Van Riel, C. B. M. (2004). Fame and Fortune: How Successful Companies Build Winning Reputation. New Jersey: Pearson Education.

Foroudi, P., Jin, Z., Gupta, S., Melewar, T. C., \& Foroudi, M. M. (2016). Influence of innovation capability and customer experience on reputation and loyalty. Journal of Business Research, 69, 4882-4889. doi: 10.1016/j.jbusres.2016.04.047

Gatzert, N., \& Schmit, J. (2016). Supporting strategic success through enterprise-wide reputation risk management. The Journal of Risk Finance, 17(1), 26-45. doi: 10.1108/JRF-09-2015-0083

George, D., \& Mallery, P. (2016). IBM SPSS Statistics 23 Step by Step: A Simple Guide and Reference $\left(14^{\text {th }}\right.$ ed.). New York: Routledge.

Goldring, D. (2015). Reputation orientation improving marketing performance through corporate reputation building. Marketing Intelligence \& Planning, 33(5), $784-803$.

Guilford, J. P. (1956). Fundamental Statistics in Psychology and Education (3 ${ }^{\text {rd }}$.). New York: McGraw-Hill. 
Hair, J. F., Black, W. C., Babin, B. J., \& Anderson, R. E. (2018). Multivariate Data Analysis. (8 ${ }^{\text {th }}$ ed.). Cengage Learning EMEA

Halff, G. (2013). The presentation of CEOs in economic downturn. Corporate Reputation Review, 16(3), 234-243.

Kanto, D. S., de Run, E. C., \& Md Isa, A. H. (2013). Developing an alternative measurement of corporate reputation within the Malaysian context. Interdisciplinary Journal of Contemporary Research in Business, 5(1), 730-738.

Kanto, D. S., De Run, E. C., \& Md Isa, A. H. (2016). The Reputation Quotient as a corporate reputation measurement in the Malaysian banking industry: A confirmatory factor analysis. Procedia Social and Behavioral Sciences, 219, 409-415. doi:10.1016/j.sbspro.2016.05.062

Kumari, S. S. S. (2008). Multicollinearity: Estimation and elimination. Journal of Contemporary Research in Management, 3(1), 87-95.

Lu, Y. J., Abeysekera, I., \& Cortese, C. (2015). Corporate social responsibility reporting quality, board characteristics and corporate social reputation: Evidence from China. Pacific Accounting Review, 27(1), 1-50. doi: 10.1108/PAR-10-2012-0053

Lu, J. f., Jing, R. T., \& Cao, Q. (2014). Antecedents of corporate reputation and customer citizenship behavior: Evidence from China. International Business and Management, 9(1), 128-132. doi: 10.3968/5112

Makkonen, T., \& Inkinen, T. (2014). Innovation quality in knowledge cities: Empirical evidence of innovation award competitions in Finland. Expert Systems with Applications, 41, 5597-5604. doi: 10.1016/j.eswa.2014.02.010

Men, L. R. (2014). Internal reputation management: The impact of authentic leadership and transparent communication. Corporate Reputation Review, 17(4), 254-272. doi:10.1057/crr.2014.14

Sah, M. N. F., \& Abdullah, Z. (2014). The customer's perception toward Secret Recipe's reputation by using the RepTrak ${ }^{\mathrm{TM}}$ model. Proceedings of the $1^{\text {st }}$ AAGBS International Conference on Business Management (AiCoBM 2014).

Mukaka, M. M. (2012). Statistics corner: A guide to appropriate use of correlation coefficient in medical research. Malawi Medical Journal, 24(3), 69-71.

Nunnally, J. C. (1978). Psychometric Theory (2 ${ }^{\text {nd }}$ ed.). New York, NY: McGraw-Hill.

Ogunfowora, B. (2014). The impact of ethical leadership within the recruitment context: The roles of organizational reputation, applicant personality, and value congruence. The Leadership Quarterly, 25, 528-543. doi: 10.1016/j.leaqua.2013.11.013

Orlitzky, M., \& Swanson, D. L. (2012). Assessing stakeholder satisfaction: Toward a supplemental measure of corporate social performance as reputation. Corporate Reputation Review, 15(2), 119-137.

Pallant, J. (2007). SPSS Survival Manual: A Step-By-Step Guide to Data Analysis Using SPSS Version 15. Nova lorque: McGraw-Hill.

Park, E. (2019). Corporate social responsibility as a determinant of corporate reputation in the airline industry. Journal of Retailing and Consumer Services, 47, 215-221. doi.org/10.1016/j.jretconser.2018.11.013

Ponzi, L. J., Fombrun, C. J., \& Gardberg, N. A. (2011). RepTrak ${ }^{T M}$ pulse: Conceptualizing and validating a short-form measure of corporate reputation. Corporate Reputation Review, 14(1), 15-35. doi: 10.1057/crr.2011.5

Reputation Institute. (2018). Top 100 reputable companies around the globe according to Reputation Institute's global $\operatorname{RepTrak}^{\circledR} 100$. Retrieved from 
https://globenewswire.com/news-release/2018/03/16/1441572/0/en/Top-100Reputable-Companies-Around-the-Globe-According-to-Reputation-Institute-sGlobal-RepTrak-100.html

Pitpreecha, R. (2013). Corporate reputation in Thailand: An analysis of indicators. Journal of Public Relations and Advertising, 6(1), 1-16.

Sekaran, U., \& Bougie, R. (2016). Research Methods For Business: A Skill Building Approach ( $7^{\text {th }}$ ed.). New Jersey: John Willey and Sons, Inc.

Skytrax World Airline Awards. (2018). World's top 100 airlines 2018. Retrieved from https://www.worldairlineawards.com/worlds-top-100-airlines-2018/

Stavrinoudis, T. A., \& Chrysanthopoulou, D. (2017). The role of leadership in building and managing corporate reputation of 4 and 5 star hotels. Tourism and Hospitality Research, 17(2), 176-189.

Tabachnick, B. G., \& Fidell, L. S. (2013). Using Multivariate Statistic (6 $6^{\text {th }}$ ed.). Boston: Pearson Education.

Taghian, M., D'Souza, C., \& Polonsky, M. J. (2015). A stakeholder approach to corporate social responsibility, reputation and business performance. Social Responsibility Journal, 11 (2), 340-363. doi: 10.1108/SRJ-06-2012-0068

Thompson, C. G., Kim, R. S., Aloe, A. M., \& Becker, B. J. (2017). Extracting the variance inflation factor and other multicollinearity diagnostics from typical regression results. Basic and Applied Social Psychology, 39(2), 81-90, doi: 10.1080/01973533.2016.1277529

Vidaver-Cohen, D., \& Bronn, P. S. (2013). Reputation, responsibility, and stakeholder support in Scandinavian firms: A comparative analysis. Journal of Business Ethics, 127(1), 4964. doi: 10.1007/s10551-013-1673-7

Vig, S., Dumicic, K., \& Klopotan, I. (2017). The impact of reputation on corporate financial performance: Median regression approach. Business Systems Research, 8(2), 40-58.

Wei, J., Ouyang, Z., \& Chen, A, H. (2017). Well known or well liked? The effects of corporate reputation on firm value at the onset of a corporate crisis. Strategic Management Journal, 38(10), 2103-2120. doi.org/10.1002/smj.2639

Wei, C., Yu, Z. J., \& Chen, X. N. (2017). Research on social e-commerce reputation formation and state-introduced model. Kybernetes, 46(6), 1021-1038. doi: 10.1108/K-08-20160203

Worlu, O., \& Ahmad, R. (2019). Does rebranding as name change rebuild or destroy brand equity (customer loyalty and brand reputation) after brand crisis?: The case of Malaysian Airline System (MAB). Journal of Technology Management and Business, $6(2), 11-22$.

Zhu, Y. (2014). The mediating effects of managerial skills on the relationship between managerial values, ethical leadership, and organizational reputation. Journal of AsiaPacific Business, 15(4), 335-359. doi: 10.1080/10599231.2014.965965

Zhu, Y., Sun, L. Y., \& Leung, A. S. M. (2013). Corporate social responsibility, firm reputation, and firm performance: The role of ethical leadership. Asia Pacific Journal of Management, 31(4), 925-947. doi: 10.1007/s10490-013-9369-1 